\title{
Synthesis and Characterisation of New Symmetrical Binucleating Ligands and Their Binuclear Copper(II) Complexes
}

\author{
K. Jothivenkatachalam and S. Chandra Mohan \\ Department of Chemistry, Bharathidasan Institute of Technology, Anna University, Tiruchirappalli 620024, India \\ Correspondence should be addressed to K. Jothivenkatachalam; jothivenkat@yahoo.com
}

Received 17 August 2013; Revised 27 October 2013; Accepted 10 November 2013; Published 2 January 2014

Academic Editor: Andrea Bencini

Copyright (c) 2014 K. Jothivenkatachalam and S. Chandra Mohan. This is an open access article distributed under the Creative Commons Attribution License, which permits unrestricted use, distribution, and reproduction in any medium, provided the original work is properly cited.

\begin{abstract}
New symmetrical binucleating ligands N,N-bis[2-hydroxy-5-methyl-3-(4-methyl-piperazinomethyl)benzyl]-alkylamines $\mathrm{L}^{1}$ and $\mathrm{L}^{2}$ and their copper(II) complexes $\left[\mathrm{Cu}_{2} \mathrm{~L}(\mathrm{X})_{2}\right] \cdot 2 \mathrm{H}_{2} \mathrm{O}$, where $\mathrm{X}=\mathrm{CH}_{3} \mathrm{COO}^{-}, \mathrm{C}_{6} \mathrm{H}_{5} \mathrm{COO}^{-}, \mathrm{Cl}^{-}$, and $\mathrm{ClO}_{4}^{-}$, were prepared and characterised. All the complexes undergo quasi-reversible reduction at negative potential $(\mathrm{E}=-0.48$ to $-1.02 \mathrm{~V})$. The acetate and benzoate complexes undergo a two-step single electron transfer at -0.48 to $-0.60 \mathrm{~V}$ and -0.9 to $-1.02 \mathrm{~V}$. The chloro and perchlorate complexes undergo a single step two-electron transfer at -0.55 to $-0.75 \mathrm{~V}$. Variable temperature magnetic studies show the presence of weak exchange interaction for acetate $\left(-2 \mathrm{~J}\right.$ around 25 to $\left.40 \mathrm{~cm}^{-1}\right)$ and benzoate $\left(-2 \mathrm{~J}\right.$ around 45 to $\left.55 \mathrm{~cm}^{-1}\right)$ bridged complexes and no exchange interaction is found for chloro and perchlorate complexes. ESR spectra of chloro and perchlorate complexes are like mononuclear copper(II) complexes with hyperfine splitting $\left(A=165 \pm 5, g_{\|}=2.17-2.23\right.$, and $\left.g_{\perp}=2.05-2.10\right)$. The ESR spectra of acetate and benzoate complexes are like binuclear copper(II) complexes with broad signal $(g=2.2)$.
\end{abstract}

\section{Introduction}

Interest in the synthesis of new binucleating ligands with different donor atoms and flexibility [1-6] attracts the attention of several coordination chemists, because complexes prepared using these ligands emerge with peculiar chemical behaviours mainly due to their application in bioinorganic chemistry, magnetochemistry, electrochemistry, and homogeneous catalysis. This interest has arisen because such ligands can accommodate two metal centers and thus may provide the basis of models for the active sites of biological systems. Several bi- and polynuclear copper containing proteins have been identified such as hemocyanin, tyrosinase, catechol oxidases, ceruloplasmin, laccase, and ascorbate oxidase [715]. Understanding the functional and structural properties of binuclear active site by developing small dicopper complexes as models for these metalloproteins is the main aim of the bioinorganic chemist. In physicochemical aspects, these dicopper complexes have noteworthy significance as new inorganic materials capable of showing peculiar magnetic and redox properties and hence these dinuclear copper(II) complexes have wealthy applications in magnetochemistry and homogeneous catalysis [16-20]. In our laboratory we are dealing with binucleating ligands and their metal complexes for more than one decade. So far we have synthesised series of binucleating ligands with phenolic and piperazinyl donor atoms [21-29]. The magnetic and ESR spectral behaviours of the complexes are interesting. The dicopper(II) complexes of the ligand "a" $[21,22]$ are strongly antiferromagnetic, the complexes of the ligand "b" are weakly antiferromagnetic $[23,24]$, and the complexes of the ligand "c" are paramagnetic [25] as shown in Scheme 1. The present study deals with the synthesis of similar compounds like "c" in which the two 2-hydroxy-5-methyl-3-(4-methylpiperazinyl)substituted phenyl residues are separated by a $-\mathrm{CH}_{2}-\mathrm{N}-$ $\mathrm{CH}_{2}$ - fragment instead of methylene group.

\section{Experimental}

2.1. Materials and Methods. All the chemicals and reagents used in this study were obtained from Merck and Sigma Aldrich. Tetra-N-butyl ammonium perchlorate was purchased from Fluka and recrystallised from ethanol-water 
<smiles>Cc1cc(CN2CCN(C)CC2)c(O)c(CN2CCN(C)CC2)c1</smiles>

(a)<smiles>Cc1cc(C)c(O)c(CN(C)Cc2cc(C)cc(C)c2O)c1</smiles>

(b)<smiles>Cc1cc(CN2CCN(C)CC2)c(O)c(CN2CCN(C)CC2)c1</smiles>

(c)<smiles>[R]N(Cc1cc(C)cc(CN2CCN(C)CC2)c1O)Cc1cc(C)cc(CN2CCN(C)CC2)c1O</smiles>

$\mathrm{R}=\mathrm{CH}_{3}, \mathrm{C}_{2} \mathrm{H}_{5}$

(d)

SCHEME 1

mixture (caution: TBAP is potentially explosive; hence, care should be taken in the handling of this compound). HPLC grade dimethylformamide and acetonitrile were obtained from S.D. Fine chemicals.

2.2. Physical Measurements. Elemental analyses were carried out by using Carlo Erba model 1106 elemental analyser. Atomic absorption spectra were recorded on Varian AA200 model atomic absorption spectrophotometer. ${ }^{1} \mathrm{H}$ NMR $(90 \mathrm{MHz})$ spectra were recorded in $\mathrm{CDCl}_{3}$ using a $\mathrm{FX}-90 \mathrm{Q}$ Fourier transform NMR spectrometer. ${ }^{13} \mathrm{C}-\mathrm{NMR}$ spectra $(200 \mathrm{MHz})$ were recorded on a JEOL model $400 \mathrm{NMR}$ spectrometer and the EI mass spectra were recorded on a JMS DX 303-HF mass spectrometer. IR spectra were recorded on a Hitachi 320 spectrophotometer on $\mathrm{KBr}$ disks in the range $250-4000 \mathrm{~cm}^{-1}$. Electronic spectra were recorded on a Hewlett-Packard 8452 A diode array spectrophotometer in the range $250-850 \mathrm{~nm}$. Molar conductivity measurements were measured on an Elico digital conductivity bridge model M88 and conventional cell which was previously calibrated with an aqueous solution of $\mathrm{KCl}(0.1 \mathrm{~N})$.

For cyclic voltammetry, a three-electrode system was used, in which the counter and working electrode were small platinum foils and saturated $\mathrm{Ag} / \mathrm{AgCl}$ was the reference electrode. TBAP was used as the supporting electrolyte $(0.1 \mathrm{M})$ and all the solutions were around $10^{-3} \mathrm{M}$ in concentration. The cyclic voltammograms were obtained on an apparatus comprising a PAR model-173 potentiostat/galvanostat, model-175 universal programmer, model-176 coulometer, and a Perkin-Elmer Hitachi (057) $X-Y$ recorder. The measurements were carried out in DMF under oxygen free conditions. Variable temperature magnetic studies were performed on PAR model-155 vibrating sample magnetometer operating at 5000 gauss and the instrument was calibrated with metallic nickel supplied with the instrument. ESR spectra were recorded using a Bruker ER-200D-SRC spectrometer. 
<smiles>[R]N(Cc1cc(C)ccc1O)Cc1cc(C)cc(CN2CCN(C)CC2)c1O</smiles>

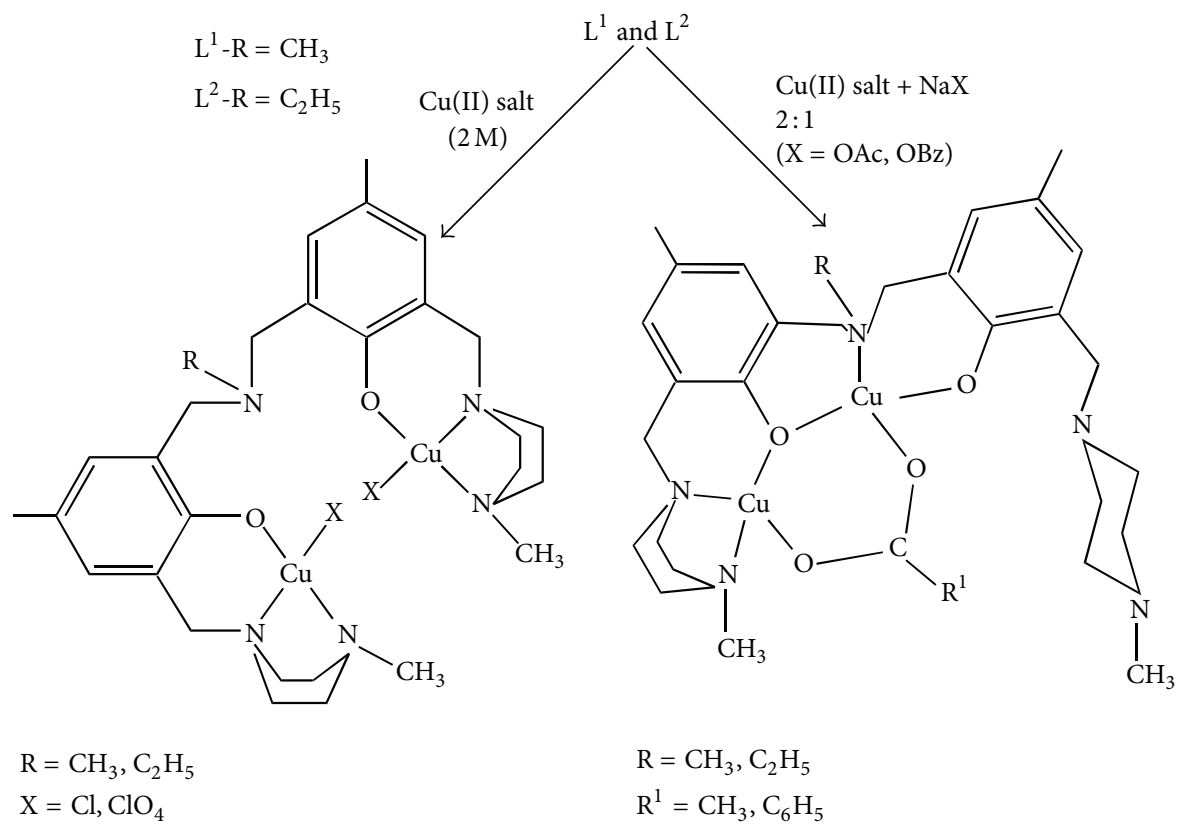

FIGURE 1: Schematic diagram for the synthesis of ligands and complexes.

2.3. Synthesis of the Ligand. The ligands, $\mathrm{L}^{1}$ and $\mathrm{L}^{2}$, were prepared by following a two-step procedure. In the first step N,N-bis[2-hydroxy-5-methylbenzyl]methylamine (PC1) and N,N-bis[2-hydroxy-5-methylbenzyl] ethylamine (PC2) were prepared by reacting p-cresol, paraformaldehyde, and primary amines in $2: 2: 1$ ratio in ethanol medium, by following the literature procedure [30]. In the second step these compounds ( $\mathrm{PCl}$ and $\mathrm{PC} 2$ ) were aminoalkylated according to the Mannich reaction with $\mathrm{N}$-methylpiperazine and formalin. The schematic diagram for the synthesis of the ligands and complexes is shown in Figure 1.

2.3.1. N,N-Bis[2-hydroxy-5-methyl-3-(4-methylpiperazinomethyl)benzyl]methylamine $L^{1}$. Paraformaldehyde $(0.75 \mathrm{~g}$, $0.025 \mathrm{~mol}$ ) was taken in $150 \mathrm{~mL}$ of glacial acetic acid and allowed to stir for 4 hours. To this $\mathrm{N}$-methylpiperazine $(2.3 \mathrm{~mL}, 0.02 \mathrm{~mol})$ was added and stirring was continued for 24 hours. The N,N-bis[2-hydroxy5-methylbenzyl] methylamine $(2.71 \mathrm{~g}, 0.01 \mathrm{~mol})$ was added and stirred for 48 hours. The resulting solution was kept at $75^{\circ} \mathrm{C}$ for about 3 hours. It was cooled and neutralised using saturated $\mathrm{Na}_{2} \mathrm{CO}_{3}$. A pasty product obtained was thoroughly washed using distilled water. Then it was extracted using dichloromethane $(350 \mathrm{~mL})$. The extracted was treated with activated charcoal and filtered. The filtrate was evaporated. A pale yellow oily substrate separated was recrystallised in benzeneethanol mixture and dried under vacuum. Mp: $71^{\circ} \mathrm{C}$. ${ }^{13} \mathrm{C}$-NMR-( $\left(\mathrm{CDCl}_{3} / 200 \mathrm{MHz} / \mathrm{TMS}\right), \delta=15.7,20.3\left(-\mathrm{CH}_{3}\right)$, $40.6,53.0,54.8,55.6,57.8$, and 60.0 (benzylic carbons), $122.3,122.5,124.4,128.0,130.7$, and 155.5 (aromatic carbons). 
${ }^{1} \mathrm{H}-\mathrm{NMR}\left(\mathrm{CDCl}_{3} / 90 \mathrm{MHz} / \mathrm{TMS}\right), \delta=1.13(\mathrm{t}, 3 \mathrm{H}), 2.21(\mathrm{~s}, 6 \mathrm{H}$, and $\left.\mathrm{N}-\mathrm{CH}_{3}\right), 2.26\left(\mathrm{~s}, 6 \mathrm{H}\right.$, and $\left.\mathrm{Ar}-\mathrm{CH}_{3}\right), 2.52(\mathrm{br}, 16 \mathrm{H}$, and piperazinyl protons), 3.6 (two close singlets, $8 \mathrm{H}$, benzylic), and 6.7-7.0 (m, 4H, and Ar-H). Mass (EI): $m / z=496(\mathrm{M}+$ 1). Anal. Calcd. for $\mathrm{C}_{29} \mathrm{H}_{45} \mathrm{~N}_{5} \mathrm{O}_{2}$ (\%): C, 70.3; $\mathrm{H}, 9.1 ; \mathrm{N}, 14.1$. Found: C, 70.1; H, 9.2; N, 14.2.

\subsubsection{N,N-Bis[2-hydroxy-5-methyl-3-(4-methyl-piperazino-} methyl)benzyl]ethylamine $L^{2}$. The above procedure was used for the preparation of this compound using N,N-bis[2hydroxy-5-methylbenzyl] ethylamine, instead of N,N-bis[2hydroxy-5-methylbenzyl]methylamine. $\mathrm{Mp}: \quad 79^{\circ} \mathrm{C} .{ }^{13} \mathrm{C}-$ NMR- $\left(\mathrm{CDCl}_{3} / 200 \mathrm{MHz} / \mathrm{TMS}\right), \delta=7.3\left(\right.$ ali- $\left.\mathrm{CH}_{3}\right), 15.6$ and $15.8\left(\mathrm{~N}-\mathrm{CH}_{3}\right.$ and $\left.\mathrm{N}-\mathrm{CH}_{2}\right), 20.3\left(\mathrm{Ar}-\mathrm{CH}_{3}\right), 40.6,54.6,55.2$, 55.8, 57.8, and 60.1 (benzylic carbons), and 122.3, 122.6, $124.4,128.1,130.8$, and 155.4 (aromatic carbons). ${ }^{1} \mathrm{H}-\mathrm{NMR}$ $\left(\mathrm{CDCl}_{3} / 90 \mathrm{MHz} / \mathrm{TMS}\right), \delta=1.13\left(\mathrm{t}, 3 \mathrm{H}\right.$, and $\mathrm{CH}_{3}$ of ethyl group), 2.21 (s, 6H, and $\left.\mathrm{N}-\mathrm{CH}_{3}\right), 2.26\left(\mathrm{~s}, 6 \mathrm{H}\right.$, and $\left.\mathrm{Ar}-\mathrm{CH}_{3}\right)$, 2.52 (br, $18 \mathrm{H}$, piperazinyl, and $\mathrm{CH}_{2}$ protons of ethyl group), 3.6 (two close singlets, $8 \mathrm{H}$, and methylene protons), and 6.7-7.0 (m, 4H, and Ar-H). Mass (EI): $m / z=510(\mathrm{M}+1)$. Anal. Calcd. for $\mathrm{C}_{30} \mathrm{H}_{47} \mathrm{~N}_{5} \mathrm{O}_{2}$ (\%): C, 70.7; H, 9.2; N, 13.8. Found: C, 70.7; H, 9.2; N, 13.7.

\subsection{Synthesis of Copper(II) Complexes}

2.4.1. $\left[\mathrm{Cu}_{2} \mathrm{~L}^{1}(\mathrm{OAc})\right] \mathrm{ClO}_{4} \cdot 2 \mathrm{H}_{2} \mathrm{O}$. (1). To a hot methanoldichloromethane $(2: 1,50: 25 \mathrm{v} / \mathrm{v})$ solution of the ligand $\mathrm{L}^{1}$ $(1.0 \mathrm{~g}, 2 \mathrm{mmol})$ copper(II) perchlorate hexahydrate $(1.48 \mathrm{~g}$, $4 \mathrm{mmol}$ ) was added, and the mixture was refluxed on a water bath for 2 hours. Then sodium acetate trihydrate $(2.7216 \mathrm{~g}$, $2 \mathrm{mmol}$ ) dissolved in minimum amount of water was added and refluxed for one more hour. The resulting solution was filtered and kept at room temperature for few days. The green precipitate separated was filtered off, washed with cold methanol and a little diethyl ether, and dried under vacuum. Yield $1.15 \mathrm{~g}$ (70.6\%). Anal. Calcd. for $\mathrm{C}_{31} \mathrm{H}_{50} \mathrm{ClCu}_{2} \mathrm{~N}_{5} \mathrm{O}_{10}$ (\%): C, 45.7; H, 6.1; Cu, 15.6; N, 8.6. Found: C, 45.1; H, 6.0; $\mathrm{Cu}, 15.5 ; \mathrm{N}, 8.4$.

2.4.2. $\left[\mathrm{Cu}_{2} \mathrm{~L}^{2}(\mathrm{OAc})\right] \mathrm{ClO}_{4} \cdot 2 \mathrm{H}_{2} \mathrm{O}$. (2). The above procedure was used for the preparation of this complex using ligand $\mathrm{L}^{2}(1.018 \mathrm{~g}, 2 \mathrm{mmol})$ instead of ligand $\mathrm{L}^{1}$. Green solid was obtained. Yield $1.17 \mathrm{~g}$ (70\%). Anal. Calcd. for $\mathrm{C}_{32} \mathrm{H}_{52} \mathrm{ClCu}_{2} \mathrm{~N}_{5} \mathrm{O}_{10}$ (\%): C, 46.4; $\mathrm{H}, 6.3 ; \mathrm{Cu}, 15.4 ; \mathrm{N}, 8.4$. Found: C, 45.9; H, 6.1; Cu 15.3; N, 8.2.

2.4.3. $\left[\mathrm{Cu}_{2} \mathrm{~L}^{1}(\mathrm{Benz})\right] \mathrm{ClO}_{4} \cdot 2 \mathrm{H}_{2} \mathrm{O}$. (3) and $\left[\mathrm{Cu}_{2} \mathrm{~L}^{2}(\mathrm{Benz})\right]$ $\mathrm{ClO}_{4} \cdot 2 \mathrm{H}_{2} \mathrm{O}$. (4). The procedure used for the preparation of these complexes is same as that of $\left[\mathrm{Cu}_{2} \mathrm{~L}^{1}(\mathrm{OAc})\right] \mathrm{ClO}_{4} \cdot 2 \mathrm{H}_{2} \mathrm{O}$. Here sodium benzoate $(0.298 \mathrm{~g}, 2 \mathrm{mmol})$ was used instead of sodium acetate. The reaction was carried in methanoldichloromethane mixture. Dark green solid colour was obtained Yield $1.32 \mathrm{~g}(75.42 \%)$ for (3). Anal. Calcd. for $\mathrm{C}_{36} \mathrm{H}_{52} \mathrm{ClCu}_{2} \mathrm{~N}_{5} \mathrm{O}_{10}$ (\%): C, 49.3; H, 5.9; Cu, 14.4; N, 8.0. Found: C, 49.3; H, 5.9; Cu, 14.3; N, 8.0. Dark green solid colour was obtained. Yield $1.40 \mathrm{~g}(78.6 \%)$ for (4). Anal. Calcd. for $\mathrm{C}_{37} \mathrm{H}_{54} \mathrm{ClCu}_{2} \mathrm{~N}_{5} \mathrm{O}_{10}$ (\%): C, 49.9; $\mathrm{H}, 6.0 ; \mathrm{Cu}, 14.26 ; \mathrm{N}, 7.9$. Found: C, 49.6; H, 6.1; Cu, 14.3; N, 7.7.

2.4.4. $\left[\mathrm{Cu}_{2} \mathrm{~L}^{1}(\mathrm{Cl})_{2}\right] \cdot 2 \mathrm{H}_{2} \mathrm{O}$. (5). To a hot methanolic solution $(100 \mathrm{~mL})$ of the ligand $\mathrm{L}^{1}$ (1.0 g, $\left.2 \mathrm{mmol}\right)$ copper(II) chloride dihydrate $(3.409 \mathrm{~g}, 4 \mathrm{mmol})$ was added to dissolved distilled methanol $(50 \mathrm{~mL})$ and the mixture was refluxed on a water bath for 2 hours. The resulting yellowish green solution was evaporated at room temperature for several days, filtered off, washed with water, followed by little diethyl ether, and dried under vacuum. Yellowish green precipitate was obtained. Yield $0.95 \mathrm{~g}$ (65.5\%). Anal. Calcd. for (5) $\mathrm{C}_{29} \mathrm{H}_{47} \mathrm{Cl}_{2} \mathrm{Cu}_{2} \mathrm{~N}_{5} \mathrm{O}_{4}$ (\%): C, 47.9; H, 6.5; Cu, 17.4; N, 9.6. Found: C, 47.8; H, 6.4; $\mathrm{Cu}$, $17.3 ; \mathrm{N}, 9.7$.

2.4.5. $\left[\mathrm{Cu}_{2} \mathrm{~L}^{2}(\mathrm{Cl})_{2}\right] \cdot 2 \mathrm{H}_{2} \mathrm{O}$. (6). This complex was prepared by following the above procedure using ligand $\mathrm{L}^{2}(1.018 \mathrm{~g}$, $2 \mathrm{mmol}$ ) instead of ligand $\mathrm{L}^{1}$. Green solid colour was obtained. Yield $1.05 \mathrm{~g}$ (70.9\%). Anal. Calcd. for (6) $\mathrm{C}_{30} \mathrm{H}_{49} \mathrm{Cl}_{2} \mathrm{Cu}_{2} \mathrm{~N}_{5} \mathrm{O}_{4}$ (\%): C, 48.6; $\mathrm{H}, 6.6 ; \mathrm{Cu}, 17.4 ; \mathrm{N}$, 9.44. Found: $\mathrm{C}, 48.5 ; \mathrm{H}, 6.6 ; \mathrm{Cu}, 17.3 ; \mathrm{N}, 9.4$.

2.4.6. $\left[\mathrm{Cu}_{2} \mathrm{~L}^{1}\left(\mathrm{ClO}_{4}\right)_{2}\right] \cdot 2 \mathrm{H}_{2} \mathrm{O}$. (7). This complex was prepared by following the procedure adopted for the preparation of (1), and no sodium acetate was added. Dark green solid colour was obtained. Yield $1.21 \mathrm{~g}(70.8 \%)$. Anal. Calcd. For (7) $\mathrm{C}_{29} \mathrm{H}_{47} \mathrm{Cl}_{2} \mathrm{Cu}_{2} \mathrm{~N}_{5} \mathrm{O}_{12}$ (\%): C, 40.7; H, 5.5; Cu, 14.9; N, 8.2. Found: C, 40.6; H, 5.4; Cu, 14.8; N, 8.13.

2.4.7. $\left[\mathrm{Cu}_{2} \mathrm{~L}^{2}\left(\mathrm{ClO}_{4}\right)_{2}\right] \cdot 2 \mathrm{H}_{2} \mathrm{O}$. (8). The above procedure was used, using ligand $\mathrm{L}^{2}$ (1.018 g, $2 \mathrm{mmol}$ ) instead of ligand $\mathrm{L}^{1}$. Dark green-coloured product formed was filtered, washed with water, and dried under a vacuum. Yield $1.15 \mathrm{~g}(66.4 \%)$. Anal. Calcd. for (8) $\mathrm{C}_{30} \mathrm{H}_{49} \mathrm{Cl}_{2} \mathrm{Cu}_{2} \mathrm{~N}_{5} \mathrm{O}_{12}$ (\%): C, 41.4; H, 5.6; $\mathrm{Cu}, 14.7 ; \mathrm{N}, 8.1$. Found: C, 41.3; H, 5.6; Cu, 14.6; N, 8.0.

All these complexes (1-8) are recrystallised and not able to obtain crystals suitable for X-ray studies.

\section{Results and Discussion}

The ligands $\left(\mathrm{L}^{1}\right.$ and $\left.\mathrm{L}^{2}\right)$ were characterised by analytical method and mass spectral studies. In the ${ }^{1} \mathrm{H}-\mathrm{NMR}$ spectra the peaks for aromatic hydrogens appear around $\delta=6.7-$ 7.0, benzylic protons appear around $\delta=3.6, \mathrm{~N}$-methyl of the piperazine residue and aromatic methyl protons appear around $\delta=2.2$, piperazinyl protons appear as a broad peak in the region $\delta=2.5$, and the aliphatic methyl protons appear at $\delta=1.13$. In the ${ }^{13} \mathrm{C}-\mathrm{NMR}$, signals for the aliphatic carbon atoms were observed in the region $\delta=7$ to 61 , and the signals for the aromatic carbon atoms were observed in the region $\delta=121$ to 156 . The IR spectra of all the complexes show broad bands in the region around $3450 \mathrm{~cm}^{-1}$ indicating the presence of coordinated or lattice water in the complexes [25, 26]. Characteristic peak for acetate was observed at $1540 \mathrm{~cm}^{-1}$ and peak for the perchlorate anion was observed at $1100 \mathrm{~cm}^{-1}$. 
TABLE 1: Electronic spectral data for the complexes (in methanol).

\begin{tabular}{|c|c|c|c|c|}
\hline No. & Complexes & $d-d$ & $\begin{array}{c}\text { LMCT } \\
{\left[\lambda_{\max }(\mathrm{nm})\left(\varepsilon, \mathrm{M}^{-1} \mathrm{~cm}^{-1}\right)\right]}\end{array}$ & LLCT \\
\hline 1 & {$\left[\mathrm{Cu}_{2} \mathrm{~L}^{1}(\mathrm{OAc})\right] \mathrm{ClO}_{4} \cdot 2 \mathrm{H}_{2} \mathrm{O}$} & $650(184)$ & $388(1270)$ & $\begin{array}{l}288(15800) \\
248(19500)\end{array}$ \\
\hline 2 & {$\left[\mathrm{Cu}_{2} \mathrm{~L}^{2}(\mathrm{OAc})\right] \mathrm{ClO}_{4} \cdot 2 \mathrm{H}_{2} \mathrm{O}$} & $664(297)$ & $436(1330)$ & $\begin{array}{l}288(15500) \\
246(19700)\end{array}$ \\
\hline 3 & {$\left[\mathrm{Cu}_{2} \mathrm{~L}^{1}(\mathrm{Benz})\right] \mathrm{ClO}_{4} \cdot 2 \mathrm{H}_{2} \mathrm{O}$} & $650(143)$ & $390(687)$ & $\begin{array}{l}292(10900) \\
242(18600)\end{array}$ \\
\hline 4 & {$\left[\mathrm{Cu}_{2} \mathrm{~L}^{2}(\mathrm{Benz})\right] \mathrm{ClO}_{4} \cdot 2 \mathrm{H}_{2} \mathrm{O}$} & $645(220)$ & $396(1200)$ & $\begin{array}{l}287(15200) \\
248(17200)\end{array}$ \\
\hline 5 & {$\left[\mathrm{Cu}_{2} \mathrm{~L}^{1} \mathrm{Cl}_{2}\right] \cdot 2 \mathrm{H}_{2} \mathrm{O}$} & $650(290)$ & $420(1310)$ & $\begin{array}{l}284(14100) \\
244(19800)\end{array}$ \\
\hline 6 & {$\left[\mathrm{Cu}_{2} \mathrm{~L}^{2} \mathrm{Cl}_{2}\right] \cdot 2 \mathrm{H}_{2} \mathrm{O}$} & 638 (249) & $412(540)$ & $\begin{array}{l}286(12500) \\
238(13000)\end{array}$ \\
\hline 7 & {$\left[\mathrm{Cu}_{2} \mathrm{~L}^{1}\left(\mathrm{ClO}_{4}\right)_{2}\right] \cdot 2 \mathrm{H}_{2} \mathrm{O}$} & 657 (208) & 405 (sh) & $\begin{array}{l}287(14700) \\
235(16300)\end{array}$ \\
\hline 8 & {$\left[\mathrm{Cu}_{2} \mathrm{~L}^{2}\left(\mathrm{ClO}_{4}\right)_{2}\right] \cdot 2 \mathrm{H}_{2} \mathrm{O}$} & $658(192)$ & 410 (sh) & $\begin{array}{l}285(13300) \\
234(14900)\end{array}$ \\
\hline
\end{tabular}

CT: charge transfer, Sh: shoulder.

TABLE 2: Electrochemical data for the complexes (in $\mathrm{dmf}^{\mathrm{a}}$ ).

\begin{tabular}{|c|c|c|c|c|c|c|c|}
\hline No. & Complexes & $E^{1} \mathrm{pc} / \mathrm{v}$ & $E^{1} \mathrm{pa} / \mathrm{v}$ & $\begin{array}{c}E_{1 / 2}^{1} / \mathrm{v} \\
(\Delta E / \mathrm{mv})\end{array}$ & $E^{2} \mathrm{pc} / \mathrm{v}$ & $E^{2} \mathrm{pa} / \mathrm{v}$ & $\begin{array}{c}E_{1 / 2}^{2} / \mathrm{V} \\
(\Delta E / \mathrm{mv})\end{array}$ \\
\hline 1 & {$\left[\mathrm{Cu}_{2} \mathrm{~L}^{1}(\mathrm{OAc})\right] \mathrm{ClO}_{4} \cdot 2 \mathrm{H}_{2} \mathrm{O}$} & -0.52 & -0.36 & $-0.44(160)$ & -0.94 & -0.70 & $0.82(240)$ \\
\hline 2 & {$\left[\mathrm{Cu}_{2} \mathrm{~L}^{2}(\mathrm{OAc})\right] \mathrm{ClO}_{4} \cdot 2 \mathrm{H}_{2} \mathrm{O}$} & -0.58 & -0.42 & $-0.50(160)$ & -0.91 & -0.75 & $-0.80(160)$ \\
\hline 3 & {$\left[\mathrm{Cu}_{2} \mathrm{~L}^{1}(\mathrm{Benz})\right] \mathrm{ClO}_{4} \cdot 2 \mathrm{H}_{2} \mathrm{O}$} & -0.50 & -0.34 & $-0.42(160)$ & -0.98 & -0.74 & $-0.86(240)$ \\
\hline 4 & {$\left[\mathrm{Cu}_{2} \mathrm{~L}^{2}(\mathrm{Benz})\right] \mathrm{ClO}_{4} \cdot 2 \mathrm{H}_{2} \mathrm{O}$} & -0.48 & -0.32 & $-0.40(160)$ & -1.02 & -0.88 & $-0.85(140)$ \\
\hline 5 & {$\left[\mathrm{Cu}_{2} \mathrm{~L}^{1} \mathrm{Cl}_{2}\right] \cdot 2 \mathrm{H}_{2} \mathrm{O}$} & -0.66 & -0.52 & $-0.59(140)$ & - & - & - \\
\hline 6 & {$\left[\mathrm{Cu}_{2} \mathrm{~L}^{2} \mathrm{Cl}_{2}\right] \cdot 2 \mathrm{H}_{2} \mathrm{O}$} & -0.72 & -0.50 & $-0.61(220)$ & - & - & - \\
\hline 7 & {$\left[\mathrm{Cu}_{2} \mathrm{~L}^{1}\left(\mathrm{ClO}_{4}\right)_{2}\right] \cdot 2 \mathrm{H}_{2} \mathrm{O}$} & -0.68 & -0.50 & $-0.59(180)$ & - & - & - \\
\hline 8 & {$\left[\mathrm{Cu}_{2} \mathrm{~L}^{2}\left(\mathrm{ClO}_{4}\right)_{2}\right] \cdot 2 \mathrm{H}_{2} \mathrm{O}$} & -0.70 & -0.48 & $-0.59(220)$ & - & - & - \\
\hline
\end{tabular}

${ }^{\text {a }}$ Potential $V$ versus SCE. Conditions: Pt working and SCE reference electrodes; supporting electrolyte: TBAP; concentration: complex $\left(1 \times 10^{-3} \mathrm{M}\right)$, TBAP $\left(1 \times 10^{-1} \mathrm{M}\right)$.

3.1. Electronic Spectra. Electronic spectra of all the complexes were studied in methanolic medium, and the data are summarised in Table 1. For dicopper complexes, the absorption spectra exhibit three main features, two high energy intense peaks below $300 \mathrm{~nm}$ assigned to the intraligand charge transfer transitions (LLCT), a peak or shoulder around $400 \mathrm{~nm}$ $\left(\varepsilon \approx 2000 \mathrm{dm}^{3} \mathrm{~mol}^{-1}\right)$ due to phenolate to copper charge transfer transitions (LMCT) [31-34], and weak band around $630-670 \mathrm{~nm}\left(\varepsilon \approx 300 \mathrm{dm}^{3} \mathrm{~mol}^{-1}\right)$ for the usual copper $\mathrm{d}-\mathrm{d}$ transitions.

3.2. Electrochemistry. The electrochemical behaviour of the complexes was studied by cyclic voltammetry and the electrochemical data such as cathodic peak potential $\left(E_{p c}\right)$, anodic peak potential $\left(E_{p a}\right)$, peak separation $\left(\Delta E_{p}\right)$, and redox potential $E_{1 / 2}$ are given in Table 2 . The typical cyclic voltammogram for the complexes $\mathbf{2}$ and $\mathbf{8}$ is given in Figure 2. The cyclic voltammogram of the complexes bridged by acetate and benzoate exogenous donor atoms shows two well defined quasi-reversible redox waves in the potential range -0.2 to $-1.2 \mathrm{~V}$. However, for the chloro and perchlorate complexes only one redox wave in the potential range -0.55 to $-0.75 \mathrm{~V}$ was observed. In order to ascertain the mechanism of the electrochemical reduction, coulometric measurement was carried out. At a potential $-1.10 \mathrm{~V}$, the acetate and benzoate complexes consumed 2 electrons per mole of the complexes $(n=1.94)$ and at a potential $-0.70 \mathrm{~V}$ the complexes consumed only one electron $(n=0.95)$ per molecule, which indicate that the involvement of two single electron transfers in the reduction processes of these complexes. Based on the coulometric results, the two reduction peaks observed in the cyclic voltammograms are attributed to the two stepwise one electron transfers as observed in several binuclear copper(II) complexes [30, 35]. Consider

$$
\mathrm{Cu} \text { (II) } \mathrm{Cu} \text { (II) } \stackrel{\mathrm{e}-}{\rightleftharpoons} \mathrm{Cu}(\mathrm{II}) \mathrm{Cu}(\mathrm{I}) \stackrel{\mathrm{e}-}{\rightleftharpoons} \mathrm{Cu}(\mathrm{I}) \mathrm{Cu}(\mathrm{I}) \text {. }
$$

The coulometric studies of the chloro and perchlorate bridged complexes at a $-0.85 \mathrm{~V}$ indicate that the complexes 
TABLE 3: ESR spectral and magnetic data for the complexes ${ }^{\mathrm{a}}$.

\begin{tabular}{|c|c|c|c|c|c|c|c|c|}
\hline \multirow{2}{*}{ No. } & \multirow{2}{*}{ Complexes } & \multirow{2}{*}{$\mu_{\beta} / \mathrm{Cu}$ at $298 \mathrm{~K}$} & \multirow{2}{*}{$-2 \mathrm{~J} / \mathrm{cm}^{-1}$} & \multirow{2}{*}{$g$-values } & \multirow{2}{*}{$P$} & \multirow{2}{*}{$A$} & \multicolumn{2}{|c|}{$g$ from ESR } \\
\hline & & & & & & & $g_{\|}$ & $g_{\perp}$ \\
\hline 1 & {$\left[\mathrm{Cu}_{2} \mathrm{~L}^{1}(\mathrm{OAc})\right] \mathrm{ClO}_{4} \cdot 2 \mathrm{H}_{2} \mathrm{O}$} & 1.56 & 26 & 2.20 & 0.003 & - & - & - \\
\hline 2 & {$\left[\mathrm{Cu}_{2} \mathrm{~L}^{2}(\mathrm{OAc})\right] \mathrm{ClO}_{4} \cdot 2 \mathrm{H}_{2} \mathrm{O}$} & 1.52 & 38 & 2.20 & 0.003 & - & - & - \\
\hline 3 & {$\left[\mathrm{Cu}_{2} \mathrm{~L}^{1}(\mathrm{Benz})\right] \mathrm{ClO}_{4} \cdot 2 \mathrm{H}_{2} \mathrm{O}$} & 1.45 & 53 & 2.20 & 0.001 & - & - & - \\
\hline 4 & {$\left[\mathrm{Cu}_{2} \mathrm{~L}^{2}(\mathrm{Benz})\right] \mathrm{ClO}_{4} \cdot 2 \mathrm{H}_{2} \mathrm{O}$} & 1.50 & 48 & 2.20 & 0.002 & - & - & - \\
\hline 5 & {$\left[\mathrm{Cu}_{2} \mathrm{~L}^{1} \mathrm{Cl}_{2}\right] \cdot 2 \mathrm{H}_{2} \mathrm{O}$} & 1.72 & - & - & - & 165 & 2.17 & 2.05 \\
\hline 6 & {$\left[\mathrm{Cu}_{2} \mathrm{~L}^{2} \mathrm{Cl}_{2}\right] \cdot 2 \mathrm{H}_{2} \mathrm{O}$} & 1.73 & - & - & - & 170 & 2.23 & 2.10 \\
\hline 7 & {$\left[\mathrm{Cu}_{2} \mathrm{~L}^{1}\left(\mathrm{ClO}_{4}\right)_{2}\right] \cdot 2 \mathrm{H}_{2} \mathrm{O}$} & 1.71 & - & - & - & 160 & 2.20 & 2.10 \\
\hline 8 & {$\left[\mathrm{Cu}_{2} \mathrm{~L}^{2}\left(\mathrm{ClO}_{4}\right)_{2}\right] \cdot 2 \mathrm{H}_{2} \mathrm{O}$} & 1.72 & - & - & - & 160 & 2.22 & 2.09 \\
\hline
\end{tabular}

${ }^{a} N_{\alpha}$ has been fixed as $120 \times 10^{-6} \mathrm{~cm}^{3} /$ mole for all magnetic simulations.

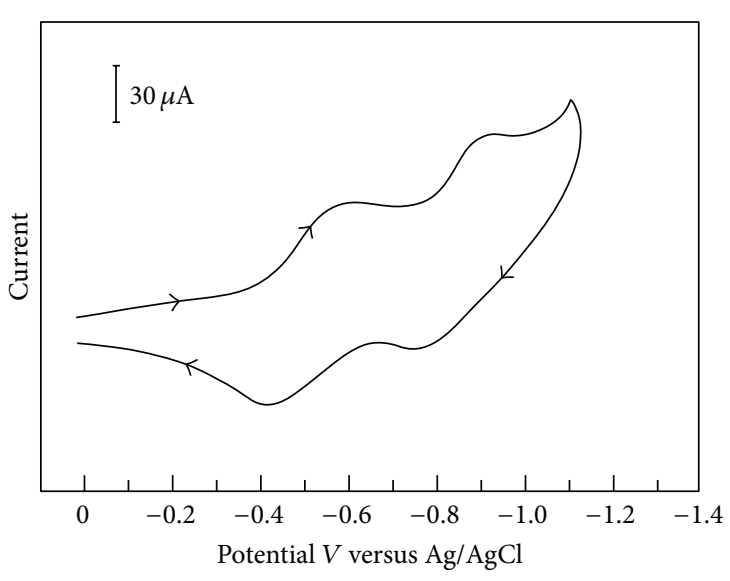

(a)

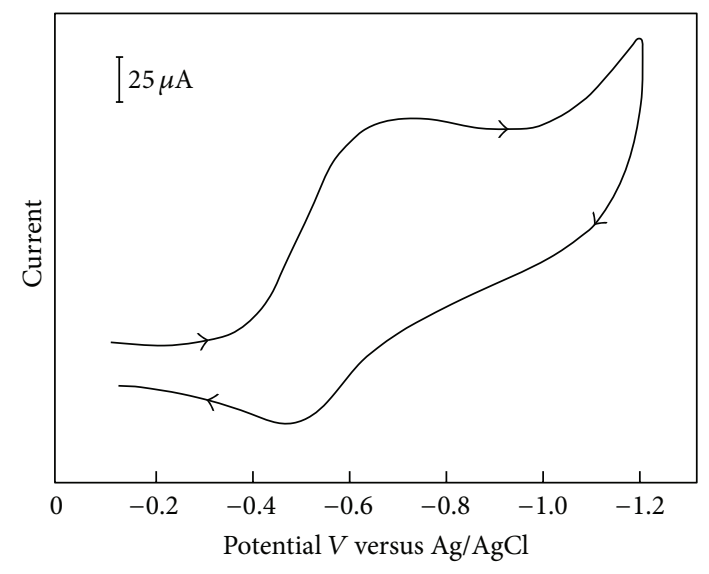

(b)

FIgURe 2: Cyclic voltammogram for the complexes (a) $\left[\mathrm{Cu}_{2} \mathrm{~L}^{2}(\mathrm{OAc})\right] \mathrm{ClO}_{4} \cdot 2 \mathrm{H}_{2} \mathrm{O}$. (2) and (b) $\left[\mathrm{Cu}_{2} \mathrm{~L}^{2}\left(\mathrm{ClO}_{4}\right)_{2}\right] \cdot 2 \mathrm{H}_{2} \mathrm{O} \cdot(\mathbf{6})$.

consumed two electrons per molecule $(n=1.86)$, showing typical electrochemical behaviour of remote donor set copper(II) complexes [36, 37]. Consider

$$
\mathrm{Cu}(\mathrm{II}) \mathrm{Cu}(\mathrm{II}) \stackrel{2 \mathrm{e}-}{\rightleftharpoons} \mathrm{Cu}(\mathrm{I}) \mathrm{Cu}(\mathrm{I}) \text {. }
$$

A comparison of the reduction potentials of the complexes of a particular ligand indicates that the reduction potential is exogenous bridging donor dependent. Acetate and benzoate bridged complexes undergo two-step single electron transfer, whereas chloro and perchlorate complexes undergo single step two-electron transfer.

3.3. Magnetochemistry. Room temperature as well as variable temperature $(77-300 \mathrm{~K})$ magnetic studies were performed for all the complexes, and the magnetic data are given in Table 3. The magnetic data obtained from variable temperature magnetic studies were fitted to the modified BleaneyBowers equation $[38,39]$ to evaluate the singlet-triplet energy separation (-2 J). Consider

$$
\chi_{m}=\left(\frac{N g^{2} \beta^{2}}{3 k T}\right)\left[3+\exp \left(\frac{-2 J}{k T}\right)\right]^{-1}(1-p)+\frac{0.45 p}{T}+N_{\alpha},
$$

where $\chi_{m}$ is the molar magnetic susceptibility, $p$ is the percentage of monomeric impurities, and other symbols have their usual meanings. $N_{\alpha}$ has been fixed at $120 \times$ $10^{-6} \mathrm{~cm}^{3} \mathrm{~mol}^{-1}$ and based on ESR studies; $g$ was fixed as 2.20 for all magnetic simulations. $-2 \mathrm{~J}$ values were evaluated by a nonlinear regression analysis in which $-2 \mathrm{~J}$ and $p$ are the variables. The variation of the magnetic properties with temperature is given in Figure 3.

The room temperature magnetic moment value of the complexes 1-4 shows lower $\mu \beta / \mathrm{Cu}$ values ( $-2 \mathrm{~J}$ around 25 to $40 \mathrm{~cm}^{-1}$ for acetate, $-2 \mathrm{~J}$ around 45 to $55 \mathrm{~cm}^{-1}$ for benzoate complexes) than the spin only value, but for the complexes 5$\mathbf{8}$ it shows that $\mu \beta / \mathrm{Cu}$ values are close to the spin only values.

3.4. ESR Spectra. Both room temperature and liquid nitrogen temperature ESR spectra of the complexes were recorded in DMF and the $g$-values were evaluated using the relationship $h \nu=g \beta H$ shown in Table 3 . The ESR spectra of the complexes $\mathbf{1}$ and $\mathbf{8}$ are shown in Figure 4. In the room temperature ESR spectra, the complexes 1-4 show a broad band centered at $g-2.20$, but the complexes $\mathbf{5}-\mathbf{8}$ show poorly resolved hyperfine splitting signals $\left(g_{\|}=2.17-2.23\right.$ and $g_{\perp}=$ 2.05 to 2.10 ) which are typical of mono nuclearcopper(II) 


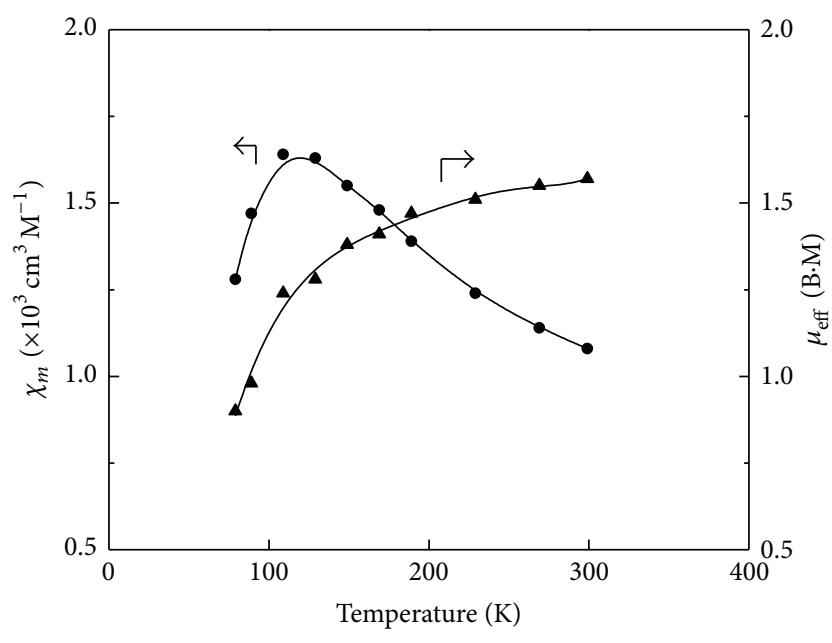

FIGURE 3: Temperature dependence magnetic properties of the complex $\left[\mathrm{Cu}_{2} \mathrm{~L}^{1}(\mathrm{OAc})\right] \mathrm{ClO}_{4} \cdot 2 \mathrm{H}_{2} \mathrm{O} \cdot(\mathbf{1})$.

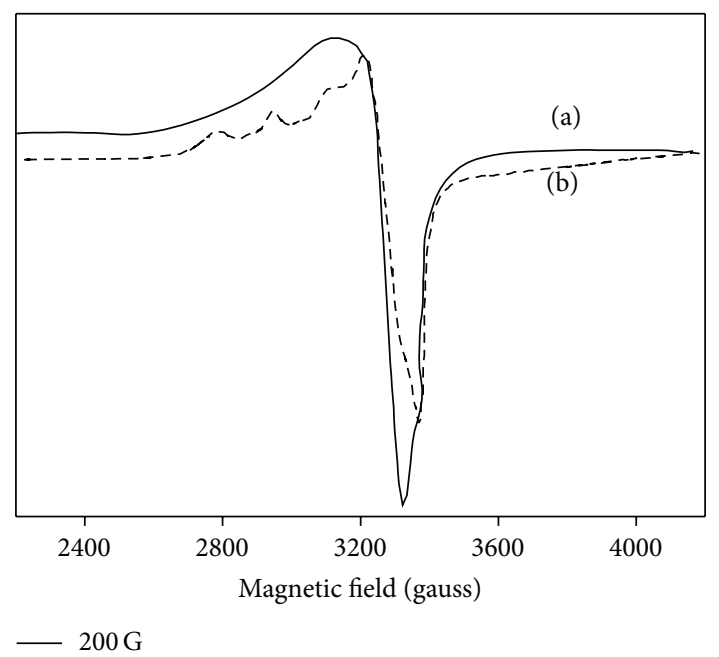

FIGURE 4: ESR Spectra for the complexes (a) $\left[\mathrm{Cu}_{2} \mathrm{~L}^{1}(\mathrm{OAc})\right]$ $\mathrm{ClO}_{4} \cdot 2 \mathrm{H}_{2} \mathrm{O}$. (1) and (b) $\left[\mathrm{Cu}_{2} \mathrm{~L}^{2}\left(\mathrm{ClO}_{4}\right)_{2}\right] \cdot 2 \mathrm{H}_{2} \mathrm{O}$. (8).

complexes and no change in the intensity of the signal at liquid nitrogen temperature was observed $[25,26,36]$.

\section{Conclusion}

Comparison of the coulometric, magnetic, and ESR spectral studies indicates that, in the complexes, the chemical behaviour varies depending upon the nature of the exogenous donor atoms. The electrochemical studies of these complexes indicate that all the complexes undergo quasireversible reduction at negative potential in the range of $E=-0.48$ to $-1.20 \mathrm{~V}$. The acetate and benzoate exogenous ligand complexes behave like a bridged binuclear system due to the presence of $\mathrm{O}-\mathrm{C}-\mathrm{O}$ bridging unit. Chloro and perchlorate ligand complexes do not form bridged binuclear complexes because of weak bridging capabilities of these ligands. Magnetic properties of these complexes indicate that there is a interaction for acetate and benzoate bridged complexes and there is no exchange interaction for chloro and perchlorate complexes. All these data indicate that the chloro and perchlorate complexes are not bridged, but the acetate and benzoate complexes are bridged.

Comparison of the chemical behaviour of the complexes of $\mathbf{c}$ with the present ligand $\mathbf{d}$ is also interesting. The unit which unites the two 2-hydroxy-5-methyl-3-(4-methylpiperazinyl)-substituted phenyl residues in $\mathbf{c}$ is $-\mathrm{CH}_{2}$ and in $\mathbf{d}$ the unit is $-\mathrm{CH}_{2}-\mathrm{N}-\mathrm{CH}_{2}$. The $\mathrm{X}$-ray structures of the ligand $\mathbf{c}$ and similar compound of $\mathrm{PC}$ of ligand $\mathbf{b}$ are relatively that of ligand $\mathbf{d}[19,21]$. In $\mathbf{c}$ both units are anti, therefore there is no possibility to form bridged binuclear complexes, but in $\mathbf{d}$ the two phenolic residues are cis, and the flexibility of the $-\mathrm{CH}_{2}-$ $\mathrm{N}-\mathrm{CH}_{2}$ - linkage may allow the molecules to come closer in the complexes of the ligand $\mathbf{d}$, leading to weak interaction between the copper atoms, and in the case of ligand such as chloride or perchlorate, formation of a bridge between the two copper atoms seems to be not possible; hence, they behave as mononuclear complexes.

\section{Conflict of Interests}

The authors declare that there is no conflict of interests.

\section{Acknowledgment}

The authors thank the Department of Science and Technology (DST), Government of India, New Delhi, for financial support, Sanction no. SR/FT/CS-042/2008.

\section{References}

[1] H. Holden Thorp and V. L. Pecoraro, Mechanistic Bioinorganic Chemistry, American Chemical Society, Washington, DC, USA, 1995.

[2] K. D. Karlin and J. Tyekler, Bioinorganic Chemistry of Copper, Chapman and Hall, New York, NY, USA, 1993.

[3] K. D. Karlin and Y. Gultneh, "Binding and activation of molecular oxygen by copper complexes," Progress in Inorganic Chemistry, vol. 35, pp. 219-327, 1987.

[4] N. Sengottuvelan, D. Saravanakumar, S. Sridevi, V. Narayanan, and M. Kandaswamy, "Macrocyclic unsymmetrical binuclear Copper(II) complexes as ligands: spectral, structural, magnetic and electrochemical studies," Supramolecular Chemistry, vol. 16, no. 2, pp. 129-136, 2004.

[5] W. Kaimand and J. Rall, "Copper-a "modern" bioelement," Angewandte Chemie, vol. 35, no. 1, pp. 43-60, 1996.

[6] E. I. Solomon, U. M. Sundaram, and T. E. Machonkin, "Multicopper oxidases and oxygenases," Chemical Reviews, vol. 96, no. 7, pp. 2563-2605, 1996.

[7] O. Kahn, "Molecular engineering of coupled polynuclear systems: orbital mechanism of the interaction between metallic centers," Inorganica Chimica Acta, vol. 62, pp. 3-14, 1982.

[8] O. Kahn, Molecular Magnetism, Wiley-VCH, New York, NY, USA, 1993.

[9] R. J. Butcher, G. Diven, G. Erickson, G. M. Mockler, and E. Sinn, "Copper complexes of binucleating N,N'-hydroxyalkyldiaminebis(salicylidine) ligands containing a $\mathrm{CuOCu}$ 
bridge and an exogenous bridge," Inorganica Chimica Acta, vol. 111, no. 2, pp. L55-L56, 1986.

[10] R. J. Butcher, G. M. Mockler, and E. Sinn, "Model compounds for the type III site and the combined type II and type III sites in multicopper oxidases," Proceedings of the Indian Academy of Sciences, vol. 102, p. 209, 1990.

[11] P. A. Vigato, S. Tamburini, and D. E. Fenton, "The activation of small molecules by dinuclear complexes of copper and other metals," Coordination Chemistry Reviews, vol. 106, pp. 25-170, 1990.

[12] H. W. Lee, N. Sengottuvelan, H.-J. Seo et al., "Structural and magnetic properties of monomeric and dimeric Copper(II) complexes with phenyl-N-[(pyridine-2yl)methylene]methaneamide," Bulletin of the Korean Chemical Society, vol. 29, no. 9, pp. 1711-1716, 2008.

[13] S. Anbu, M. Kandaswamy, P. Sathya Moorthy, M. Balasubramanian, and M. N. Ponnuswamy, "New polyaza macrobicyclic binucleating ligands and their binuclear copper(II) complexes: electrochemical, catalytic and DNA cleavage studies," Polyhedron, vol. 28, no. 1, pp. 49-56, 2009.

[14] S. Anbu, M. Kandaswamy, P. Suthakaran, V. Murugan, and B. Varghese, "Structural, magnetic, electrochemical, catalytic, DNA binding and cleavage studies of new macrocyclic binuclear copper(II) complexes," Journal of Inorganic Biochemistry, vol. 103, no. 3, pp. 401-410, 2009.

[15] G. S. Siluvai and N. N. Murthy, "X-ray structure and spectroscopic characterization of doubly-bridged binuclear copper(II) complexes in symmetric and asymmetric coordination environments," Polyhedron, vol. 28, no. 11, pp. 2149-2156, 2009.

[16] K. D. Karlin, C. X. Zhang, A. L. Rheingold, B. Galliker, S. Kaderli, and A. D. Zuberbühler, "Reversible dioxygen binding and arene hydroxylation reactions: kinetic and thermodynamic studies involving ligand electronic and structural variations," Inorganica Chimica Acta, vol. 389, pp. 138-150, 2012.

[17] U. Casellato, P. A. Vigato, D. E. Fenton, and M. Vidali, "Compartmental ligands: routes to homo- and hetero-dinuclear complexes," Chemical Society Reviews, vol. 8, no. 2, pp. 199-220, 1979.

[18] P. I. Clemenson, "The chemistry and solid state properties of nickel, palladium and platinum bis(maleonitriledithiolate) compounds," Coordination Chemistry Reviews, vol. 106, pp. 171203, 1990.

[19] P. Zanello, S. Tamburini, P. A. Vigato, and G. A. Mazzocchin, "Syntheses, structure and electrochemical characterization of homo- and heterodinuclear copper complexes with compartmental ligands," Coordination Chemistry Reviews, vol. 77, pp. 165-273, 1987.

[20] T. N. Somell, "Synthetic models for binuclear copper proteins," Tetrahedron, vol. 45, no. 1, pp. 3-68, 1989.

[21] T. M. Rajendran, Synthesis, characterization and electrochemical studies of Copper(II) complexes [Ph.D. thesis], University of Madras, 1992.

[22] K. Bertoncello, J. H. Hodgkin, and K. S. Murray, "Exogenous bridging and nonbridging in copper(II) complexes of a binucleating 2,6-bis((N-methylpiperazino)methyl)-4-chlorophenolate ligand. Crystal structures and magnetic properties of bis(.mu.acetato), dinitrito and bis(azido) complexes. Possible relevance to the type 3 depleted laccase active site," Inorganic Chemistry, vol. 27, pp. 4750-4758, 1988.

[23] P. Amudha, M. Thirumavalavan, and M. Kandaswamy, "Synthesis, spectral, electrochemical and magnetic properties of new phenoxo-bridged dicopper(II) complexes derived from unsymmetrical binucleating ligands," Polyhedron, vol. 18, no. 89, pp. 1363-1369, 1999.

[24] P. Amudha, P. Akilan, and M. Kandaswamy, "Synthesis, spectral, electrochemical and magnetic properties of new symmetrical and unsymmetrical dinuclear copper(II) complexes derived from binucleating ligands with phenol and benzimidazole donors," Polyhedron, vol. 18, no. 8-9, pp. 1355-1362, 1999.

[25] P. Kamatchi and M. Kandaswamy, "Synthesis and characterisation of copper(II) complexes derived from methylene bridged bis(tridentate) ligands," Polyhedron, vol. 17, no. 8, pp. 1397-1405, 1998.

[26] S. Annapoorani, "Synthesis and spectroscopic characterization of some Copper(II) trinuclear complexes involving Nitrogen as bridging atoms," Asian Journal of Chemistry, vol. 24, no. 8, pp. 3347-3351, 2012.

[27] P. P. Amudha, M. Kandaswamy, L. Govindasamy, and B. Velumurugan, "Synthesis and characterization of new symmetrical binucleating ligands and their $\mu$-phenoxo-bridged bicopper(II) complexes: structural, electrochemical, and magnetic studies," Inorganic Chemistry, vol. 37, no. 18, pp. 4486-4492, 1998.

[28] S. Karunakaran and M. Kandaswamy, "Synthesis, electrochemical and magnetic properties of a series of new unsymmetrical macrocyclic binuclear copper(II) complexes," Journal of the Chemical Society, Dalton Transactions, no. 10, pp. 1595-1598, 1994.

[29] S. Karunakaran and M. Kandaswamy, "Synthesis, electrochemical and magnetic properties of new acyclic "side-off" binuclear copper(II) complexes," Journal of the Chemical Society, Dalton Transactions, no. 11, pp. 1851-1855, 1995.

[30] W. J. Bruke, E. L. Marhensen Glennie, and C. Weatherbee, "Condensation of halophenols with formaldehyde and primary amines," The Journal of Organic Chemistry, vol. 29, no. 4, pp. 909-912, 1962.

[31] B. J. Hathway and G. Wilkinson, Comprehensive Coordination Chemistry, John Wiley \& Sons, New York, NY, USA, 1985.

[32] A. B. P. Lever, Inorganic Electronic Spectroscopy, Elsevier, Amsterdam, The Netherlands, 2nd edition, 1984.

[33] S. S. Hindo, R. Shakya, R. Shanmugam, M. J. Heeg, and C. N. Verani, "Metalloamphiphiles with $\left[\mathrm{Cu}_{2}\right]$ and $\left[\mathrm{Cu}_{4}\right]$ headgroups: syntheses, structures, langmuir films, and effect of subphase changes," European Journal of Inorganic Chemistry, no. 31, pp. 4686-4694, 2009.

[34] C. N. Verani, R. Shanmugam, F. R. Xavier, M. M. Allarda, and K. K. Kpogoa, "Electronic and interfacial behavior of gemini metallosurfactants with copper(II)/pseudohalide cascade cores," Dalton Transactions, vol. 42, no. 43, pp. 15296-15306, 2013.

[35] W. Mazurek, A. M. Bond, K. S. Murray, M. J. O’Connor, and A. G. Wedd, "Preparation and spectral, magnetic, and electrochemical characterization of a flexible phenoxo-bridged binuclear copper(II) complex," Inorganic Chemistry, vol. 24, no. 16, pp. 2484-2490, 1985.

[36] C. L. Chuang, K. Lim, Q. Chen, J. Zubreta, and J. M. Carary, "Synthesis, cyclic voltammetry, and x-ray crystal structures of Copper(I) and Copper(II) complexes of tris((6-phenyl-2pyridyl)methyl)amine (TPPA)," Inorganic Chemistry, vol. 34, no. 10, pp. 2562-2568, 1995.

[37] C. Fraser and B. Bosnich, "Bimetallic reactivity. Investigation of metal-metal interaction in complexes of a chiral macrocyclic binucleating ligand bearing 6- and 4-coordinate sites," Inorganic Chemistry, vol. 33, no. 2, pp. 338-346, 1994. 
[38] B. Bleaney and K. D. Bowers, "Anomalous paramagnetism of Copper acetate," Proceedings of the Royal Society A, vol. 214, no. 1119, pp. 451-465, 1952.

[39] M. Yonemura, Y. Matsumura, H. Furutachi, M. Ohba, H. Okawa, and D. E. Fenton, "Migratory transmetalation in diphenoxo-bridged CuIIMII complexes of a dinucleating macrocycle with $\mathrm{N}$ (amine $)_{2} \mathrm{O}_{2}$ and $\mathrm{N}($ amine $){ }_{2} \mathrm{O}_{2}$ metal-binding sites," Inorganic Chemistry, vol. 36, no. 13, pp. 2711-2717, 1997. 

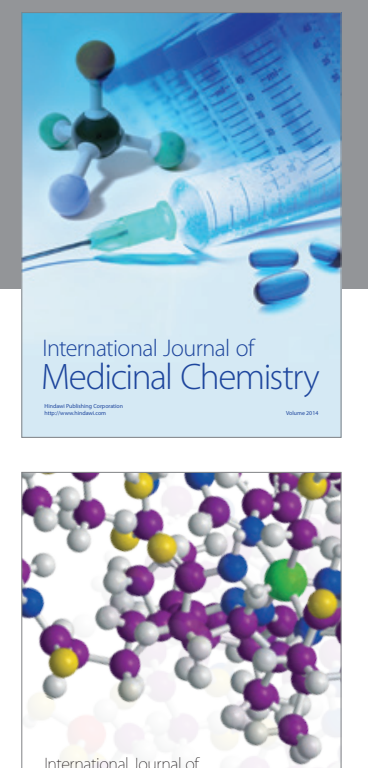

\section{Carbohydrate} Chemistry

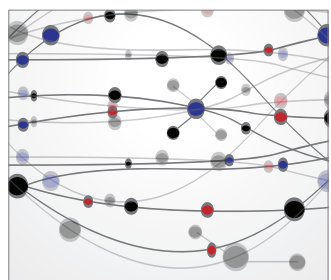

The Scientific World Journal
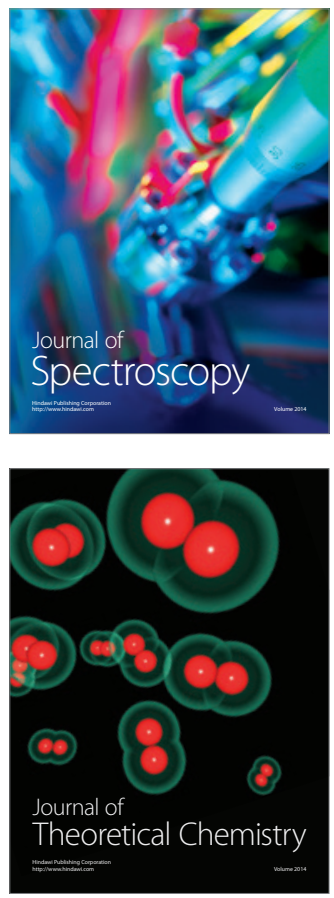
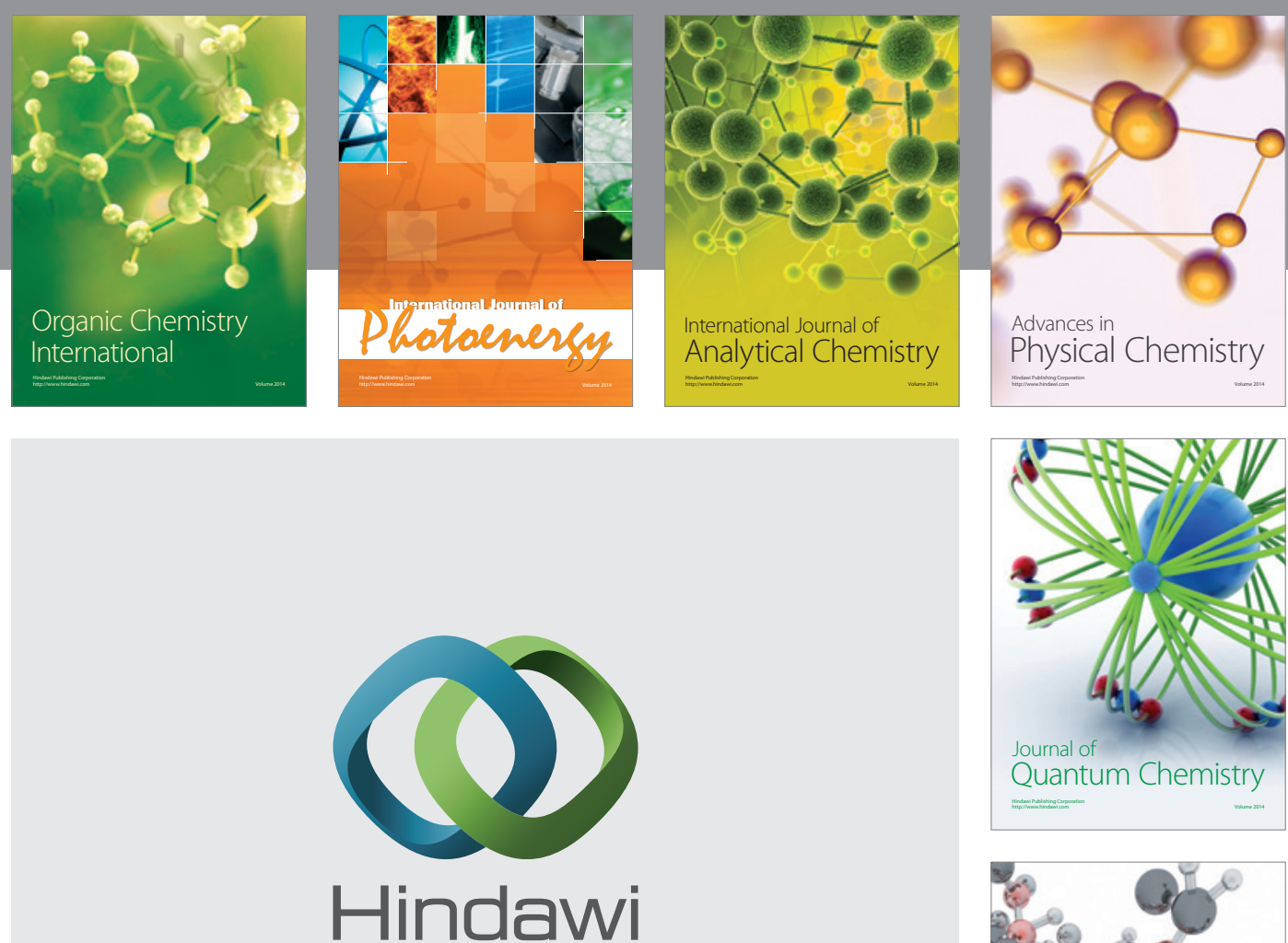

Submit your manuscripts at

http://www.hindawi.com

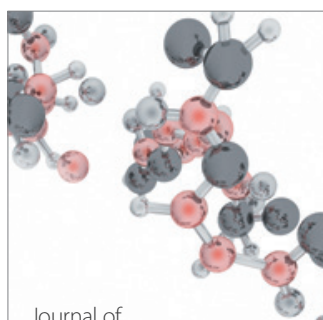

Analytical Methods

in Chemistry

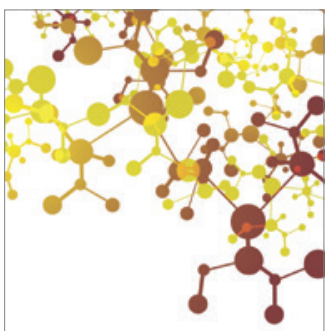

Journal of

Applied Chemistry

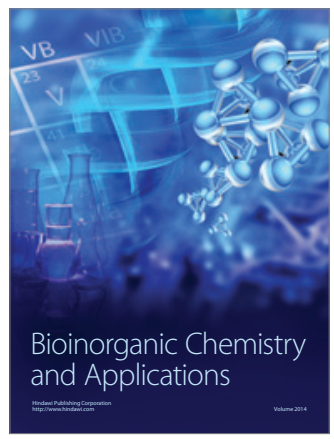

Inorganic Chemistry
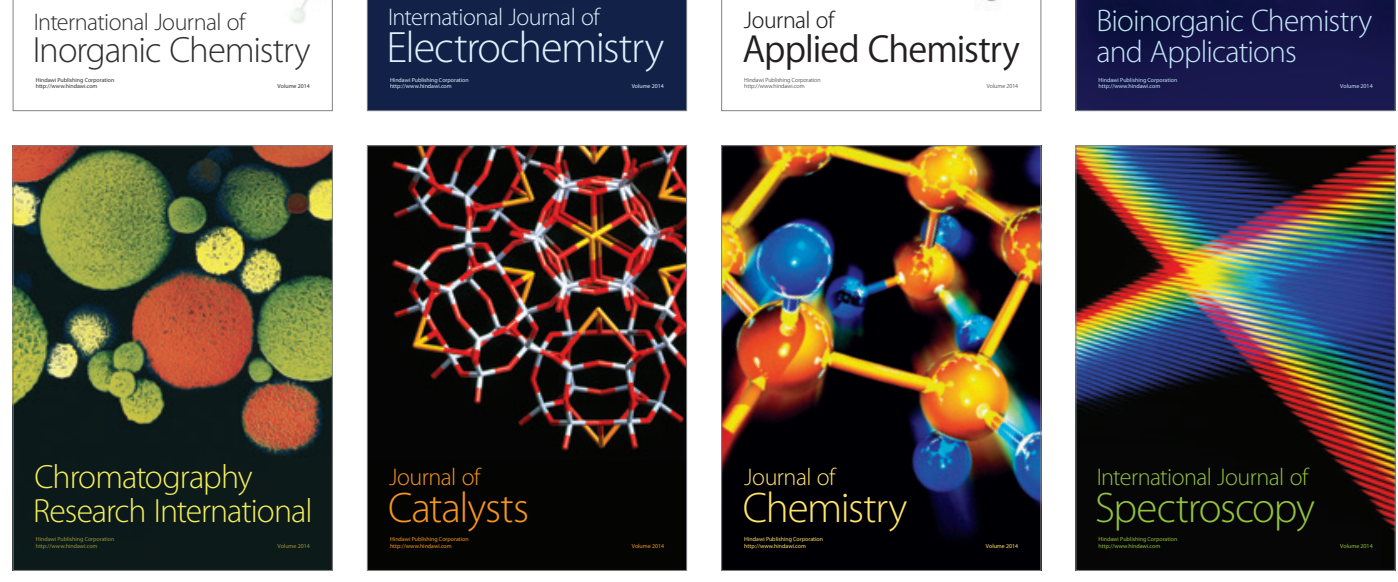